\title{
Er pårørenderollen for omfattende?
}

\author{
Pasient- og brukerrettighetsloven angir at legen må rådføre seg med de pårørende om hvilke medisiner \\ pasienten skal ha når pasienten ikke lenger kan samtykke selv. Er slik medbestemmelse gunstig for pasienten?
}

For ikke lenge siden fikk vi et trist gjensyn med den profilerte professoren og hudlegen Ole Fyrand på Dagsrevyen på NRK. Hele Norge fikk del i Fyrands demenstilstand i beste sendetid. Bakgrunnen for innslaget var at Fyrand hadde fått beroligende medikamenter på sykehjemmet uten at de pårørende var tatt med på råd. De vanlige politikerne var som alltid «sjokkert», de ansvarlige for tjenesten erklærte forbilledlig at «slik skal det ikke være» og kommentariatet kom med akkurat de kommentarene vi for-

\section{RAMME 1}

Fra pasient- og brukerrettighetsloven

§ 3-1, 3. ledd: Dersom pasienten ikke har samtykkekompetanse, har pasientens nærmeste pårørende rett til å medvirke sammen med pasienten.

$\S 4-6$ : Dersom en myndig pasient ikke har samtykkekompetanse, kan den som yter helsehjelp ta avgjørelse om helsehjelp som er av lite inngripende karakter med hensyn til omfang og varighet. Helsehjelp som innebærer et alvorlig inngrep for pasienten, kan gis dersom det anses å være i pasientens interesse, og det er sannsynlig at pasienten ville ha gitt tillatelse til slik hjelp. Der det er mulig, skal det innhentes informasjon fra pasientens nærmeste pårørende om hva pasienten ville ha ønsket. Slik helsehjelp kan besluttes av den som er ansvarlig for helsehjelpen, etter samråd med annet kvalifisert helsepersonell. Det skal fremgå av journalen hva pasientens nærmeste pårørende har opplyst, og hva annet kvalifisert helsepersonell har hatt av oppfatninger. ventet. Motforestillinger og en dypere analyse manglet fullstendig, både i Dagsrevyen og i mediediskusjonen etterpå.

Mange med demens og uro kan antakelig få en bedre hverdag med litt beroligende medikamenter. Nå er lovgivningen slik at når pasienten ikke lenger kan samtykke selv, må legen rådføre seg med de pårørende om hvilke medisiner pasienten skal ha. Dette fremgår av pasient- og brukerrettighetsloven § 3-1, 3. ledd (1) (ramme 1). Lovgiver forventer tydeligvis at tap av samtykkekompetanse hos pasienten på forunderlig vis gir pårørende kompetanse på medisinbruk og annen behandling.

\section{Plagsom medbestemmelse}

Et godt, gammelt hevdvunnet prinsipp, som riktignok i liten grad er nedfelt i noe regelverk, er at leger ikke skal behandle sine egne. Hvorfor det motsatte skal være tilfellet for pårørende som ikke er leger, kan man jo lure på. Det vil faktisk være en del tilfeller der de pårørende er de siste man bør lytte til. Jeg kjenner eksempler på at pårørendes inngripen og styring av behandling ikke bare har medført mangelfull behandling, men sågar har ført til pasientens død.

Slik er det blitt fordi helsepersonelloven (2) og pasient- og brukerrettighetsloven er laget av friske for friske. Med andre ord: av pårørende, ikke av pasienter. Ett av målene da legeloven ble erstattet av helsepersonelloven var etter min mening å rive legen ned fra pidestallen. I mangel av en stedfortreder er det de pårørende man har tydd til. Vi leger har abdisert, dels lettet over å slippe mye av ansvaret vi hadde før, men mest fordi det ikke hadde nyttet å protestere. «Alle vet» hvor fælt det var før, da en paternalistisk lege bestemte og pasienten ikke hadde noen «rettigheter». Det vil si, alle unntatt de av oss som selv har vært alvorlig syke og vet at det eneste du lengter etter når livet henger $i$ en tynn tråd er en faglig dyktig lege som kan ta de rette avgjørelsene uten å plage deg med å skulle «medbestemme» alt mulig.

Det siste jeg vil er å havne på sykehjem. Skulle det likevel bli nødvendig, for eksempel pga. demens med tap av samtykkekompetanse, håper jeg det finnes kvalifiserte sykehjemsleger som sørger for at jeg får den medisinen jeg trenger, selv om den skulle være en smule beroligende. Dessuten håper jeg det er leger som sørger for at mine pårørende slipper å måtte mene noe om dette, slik at de kan konsentrere seg om å være pårørende. Dette oppnås ved å fjerne 3 . ledd i $\S 3-1$ fra pasient- og brukerrettighetsloven og la $\S 4-6$ alene regulere det behovet som finnes for pårørendemedvirkning (ramme 1).

\section{Håkon Toft}

haktoft@online.no

Håkon Toft (f. 1950) er spesialist i allmennmedisin og i samfunnsmedisin og er pensjonert fylkeslege.

Ingen oppgitte interessekonflikter.

Litteratur

1. LOV-1999-07-02-63 Lov om pasient- og brukerrettigheter. www.lovdata.no/all/nl-19990702063.html (3.6.2013)

2. LOV-1999-07-02-64 Lov om helsepersonell m.v. www.lovdata.no/all/nl-19990702-064.html (3.6.2013).

Mottatt 21.5. 2013 og godkjent 3.6. 2013. Medisinsk redaktør Hanne Støre Valeur.

Publisert først på nett. 